\title{
A comparative study between using of Midazolam- Ketamine and Diazepam-Ketamine combinations as anaesthetic program in sheep
}

\author{
S. A. A. Al-Redah \\ Coll. of Vet.Med./ Univ. of AL-Qadisiya
}

\begin{abstract}
The present study was designed to compare the efficacy for using of the two anesthetics combinations (Midazolam-Ketamine and Diazepam-Ketamine). The effect of combinations on the length of surgical anesthesia, degree of flank analgesia, degree of muscle relaxation, respiratory rate, heart rate and rectal temperature were assayed in sheep.The experiment was conducted on ten apparently healthy adult sheep of either sex weighting $(24-33 \mathrm{~kg})$. Sheep were divided in two equal groups, Diazepam $(1 \mathrm{mg} / \mathrm{kg} \mathrm{BW})+$ Ketamine $(10 \mathrm{mg} / \mathrm{kg} \mathrm{BW})$ group $(\mathrm{D}+\mathrm{K}), \quad$ Midazolam $(1 \mathrm{mg} / \mathrm{kg} \mathrm{BW})+$ Ketamine $10 \mathrm{mg} / \mathrm{kg} \mathrm{BW}$ group $(\mathrm{M}+\mathrm{K})$, was used by intramuscular injection, benzodiazepine derivative (diazepam or midazolam) injected first and then followed by ketamine 10minutes later.The following parameter were recorded at 3 minutes before injection of drug and 5, 10, 20, 30, 45, 60 and 75 minutes (min.) respectively after administration of anaesthetic drug (Rectal Temperature, Respiratory Rate , Heart Rate , Degree of Analgesia, Degree of Muscle relaxation), the induction time, surgical anaesthesia and recovery time also were recorded.The experiment showed that the anaesthesia with Midazolam + Ketamine combination in sheep was suitable compared with Diazepam + Ketamine as it produced reliable surgical anaesthesia, good analgesia and muscle relaxation.
\end{abstract}

\section{Introduction}

Sheep are one of the most widely used reproductive animals and for humans life also for biomedical research. Rough manipulation to the sheep and when excited, may struggle vigorously, this may lead to musculoskeletal trauma, severe stress. A safe anaesthetic method is therefore needed both for surgeon undertaking research and fore practicing veterinarian. Injectable anaesthesia is preferred than inhalant anaesthesia as many complications still arise when the sheep were anaesthetized with inhalant anaesthetic because the margins of safety between anaesthetic and lethal doses are narrow. Also there are some of individual variations in response to anaesthetic agents.Injectable anaesthesia is more safer, easy and not required highly sophisticated equipment, therefore, parenteral anaesthetic are often preferred in this species. The benzodiazepines are a popular drugs used in different animal species. These drugs were reported to have minimum effect on respiratory system, heart rate, rectal temperature and reported to cause good muscle relaxation and can be used to cure convulsions. (1,2,3).
Diazepam is insoluble in water, and therefore prepared in an oily solvent that is locally irritant and can cause tissue damage and skin sloughing if administered perivascularly, while midazolam also benzodiazepine, causes minimal hemodynamic and respiratory changes (4, 5).The effects of the benzodiazepines occur at the neuronal path ways in which gamma-aminobutyric acid (GABA) is the primary neurotransmitters sedation and anticonvulsant activity is mediated by GABA (5,6).Dissociative drugs like (Ketamine and Tiletamine) a group of general anaesthetic drugs which produce anaesthesia by interrupt ascending transmission from the unconscious to conscious part of the brain rather than by generalized depression of some brain centers, Proposed mechanisms responsible for the analgesic actions of ketamine include: interaction with the C.N.S and spinal cord opiate receptors and NMDA (N-methyl-D-aspartate) receptor antagonism $(3,5,7)$. Ketamine is usually administered in combination with a tranquilizer such as diazepam, xylazine, or acetylpromazine. The use of tranquilizer 
aids muscle relaxation and allows smoother recovery than use of ketamine alone. Previously administration of an anticholinergics is suggested when ketamine is used to prevent excessive salivation. (8, 9).In viewing of some pharmacological effects of diazepam, midazolam and ketamine, there is a need for starting a study focusing on evaluation and comparison the anaesthetic activity of both combinations Diazepam+ketamine and Midazolam+ketamine and investigate their effect on length of surgical anaesthesia, degree of analgesia, degree of muscle relaxation respiratory rate, heart rate, rectal temperature in sheep.
The experiment was conducted on Ten apparently healthy adult sheep of either sex and weighting $(24-33 \mathrm{~kg})$, The animals were kept under standard management condition for two weeks with free access to feed and water. The animals were kept off feed and water for $12 \mathrm{~h}$. prior to the experiment.Experimental Design: All sheep were divided in to two equal groups *First group was injected with Diazepam $(1 \mathrm{mg} / \mathrm{kg}$ BW) +Ketamine $(10 \mathrm{mg} / \mathrm{kg} \mathrm{BW})$ I.M (D+K), diazepam was injected first and then followed by ketamine 10minutes later.

*Second group was injected with Midazolam (1mg/kg BW)+Ketamine $(10 \mathrm{mg} / \mathrm{kg}$ BW) I.M $(\mathrm{M}+\mathrm{K})$, midazolam was injected first and then followed by ketamine 10minutes later.The following parameters were recorded both before and after injection intervals $(5,10,20,30,45$, 60 and 75 minutes respectively):

\section{Results}

Induction time, surgical anaesthesia and Recovery time.After the injection of either benzodiazepines agents, the animals show less excitation after injection of midazolam compared with those injected by diazepam, the induction time in both groups were nearly similar to each other after injection of ketamine (anaesthetic drug). The surgical anaesthesia in $\mathrm{M}+\mathrm{K}$ group was significantly longer $(\mathrm{P}<0.01)$ than that showed in $\mathrm{D}+\mathrm{K}$ group, Whereas the recovery time was longer in last group. 


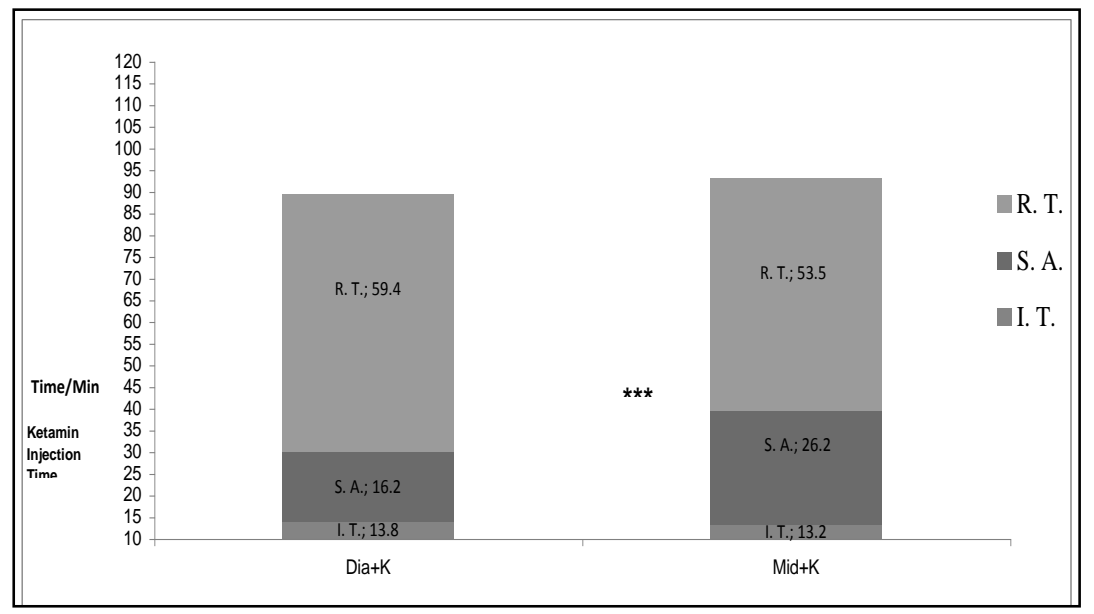

Figure ( 1 ) (I.T.: Induction Time, S.A.: Length of Surgical Anesthesia, R.T.: length of Recovery Time. To both groups $\mathrm{D}+\mathrm{K}$ and $\mathrm{M}+\mathrm{K}$, $* * *=\mathrm{P}<0.01 \%$ )

\section{Muscle Relaxation}

Muscle relaxation started at $5 \mathrm{~min}$. after im injection minimally in both groups and reach to moderate relaxation in $10 \mathrm{~min}$. The duration of muscle relaxation in $\mathrm{M}+\mathrm{K}$ group was longer than those obtained in
$\mathrm{D}+\mathrm{K}$ group, where the muscle relaxation extending from 20-60min. in $\mathrm{M}+\mathrm{K}$ group and diminished in $75 \mathrm{~min}$., while the marked relaxation in $\mathrm{D}+\mathrm{K}$ group extending from $20-45 \mathrm{~min}$. then decrease to minimal relaxation at $60 \mathrm{~min}$. figure (2).

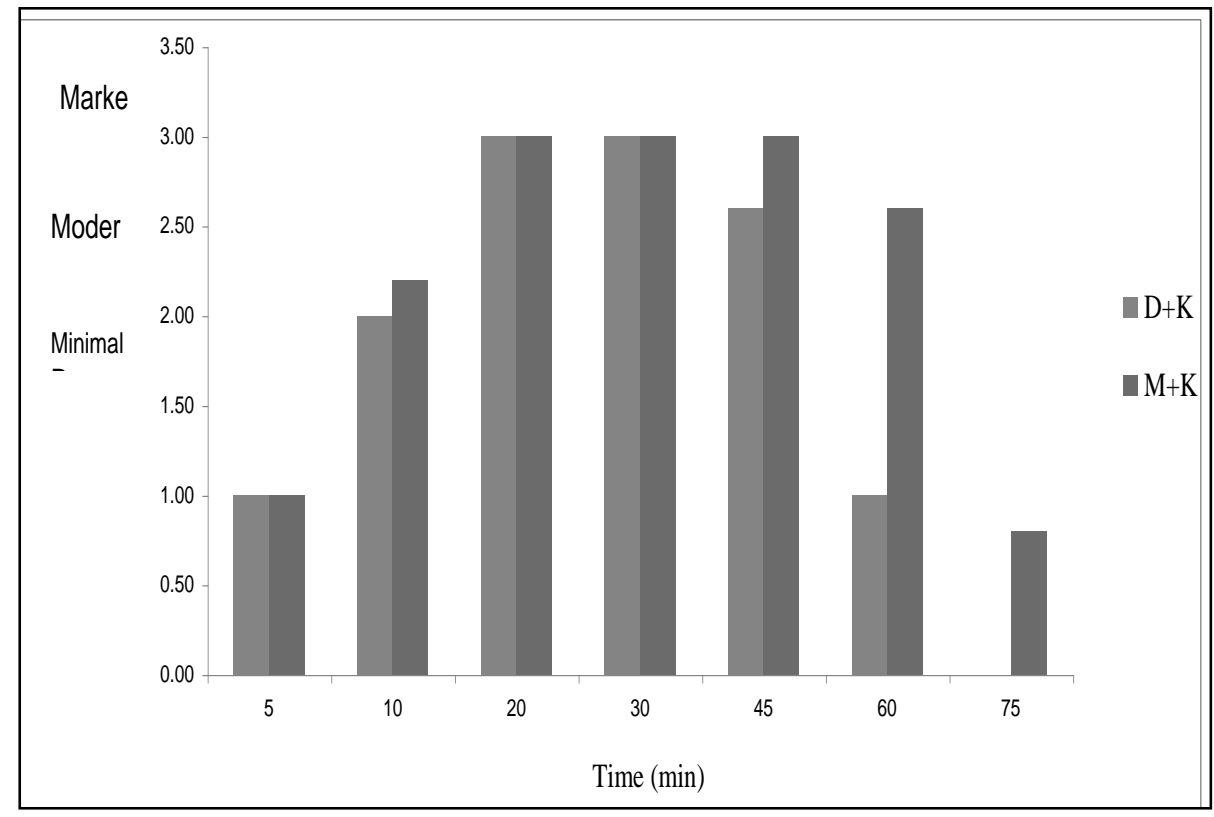

Figure (2) the effect of IM injection of $\mathrm{D}+\mathrm{K}, \mathrm{M}+\mathrm{K}$ on the Muscle relaxation:

(D: Diazepam 1mg/kg, M: Midazolam 1mg/kg, K: ketamine $10 \mathrm{mg} / \mathrm{kg}$ )

\section{Flank Analgesia}

The analgesic strength obtained after $\mathrm{M}+\mathrm{K}$ injection was relatively more than observed in $\mathrm{D}+\mathrm{K}$ group where it was mild to moderate analgesia in $\mathrm{M}+\mathrm{K}$ group at $5 \mathrm{~min}$. and $10 \mathrm{~min}$. respectively then develop to deep analgesia extending from 20-30min. and then gradually decrease to moderate and mild at $60 \mathrm{~min}$. and $75 \mathrm{~min}$. respectively, While the analgesia started moderately at $10 \mathrm{~min}$. in $\mathrm{D}+\mathrm{K}$ group then reach to deep analgesia at $20-30 \mathrm{~min}$. then to moderate analgesia at $45 \mathrm{~min}$. to disappear at 60min. figure (3). 


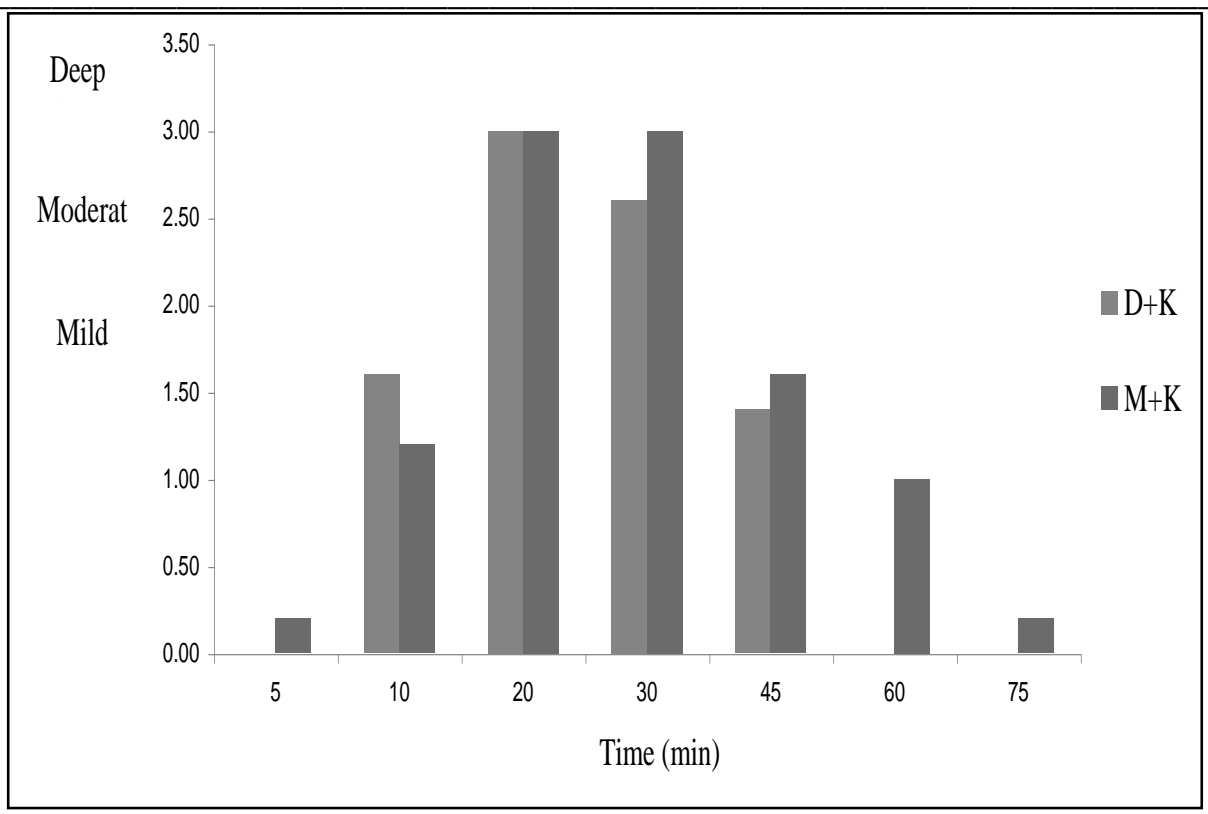

Figure (3) the effect of IM injection of D+K, M+K on Degree of Flank Analgesia:

(D: Diazepam 1mg/kg, M: Midazolam 1mg/kg, K: ketamine 10mg/kg)

\section{Respiratory Rate}

The respiratory rate in $\mathrm{M}+\mathrm{K}$ group was slowly decrease during the first 20min. after of im injection of drug to reach $27-33$ breath $/ \mathrm{min}$. at $30 \mathrm{~min}$. and $45 \mathrm{~min}$. then gradually increased to reach 41-44 breath /min. at 60-70min., While in
$\mathrm{D}+\mathrm{K}$ group the respiratory rate range from $52-55$ breath $/ \mathrm{min}$. at $5-20 \mathrm{~min}$. then gradually decrease to reach $32-45$ breath $/ \mathrm{min}$. at 30 and $75 \mathrm{~min}$. respectively figure (4).

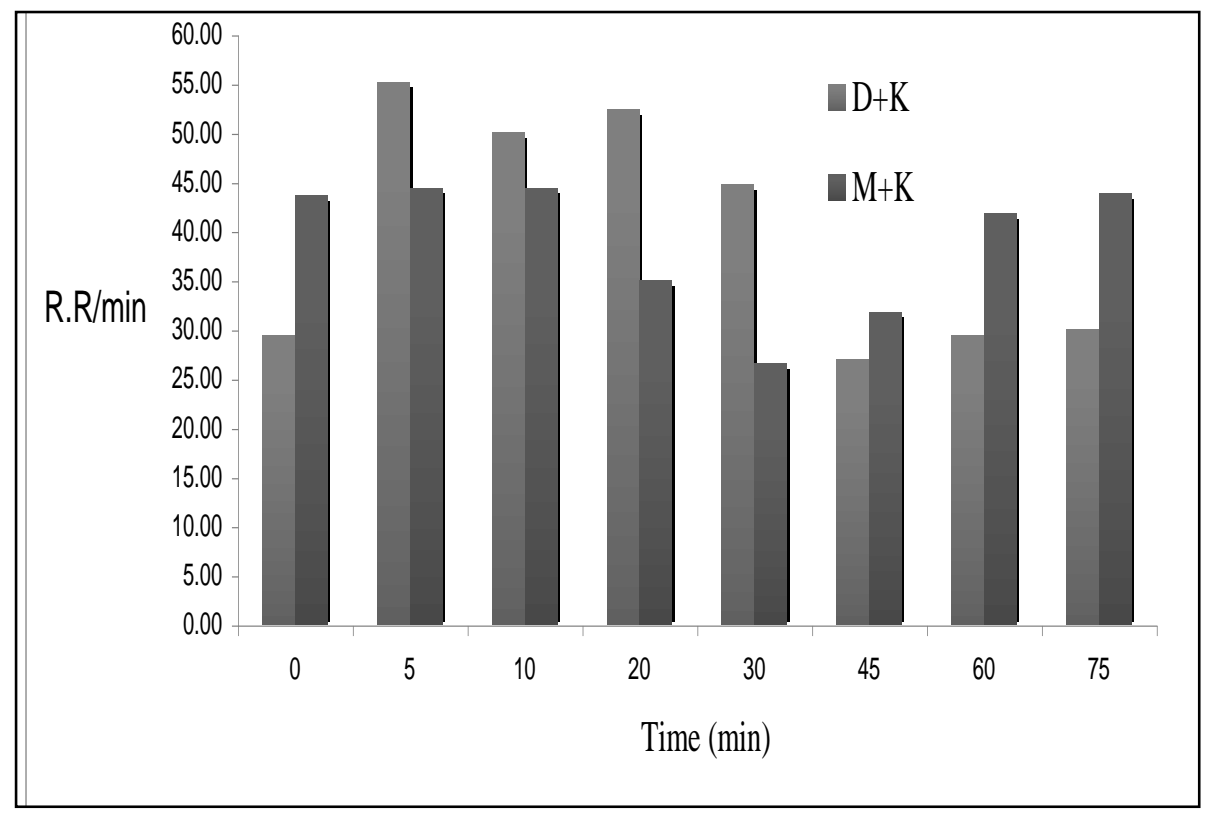

Figure (4) the effect of IM injection of $\mathrm{D}+\mathrm{K}, \mathrm{M}+\mathrm{K}$ on Respiratory Rate:

\section{Rectal Temperature}

(D: Diazepam $1 \mathrm{mg} / \mathrm{kg}, \mathrm{M}$ : Midazolam $1 \mathrm{mg} / \mathrm{kg}, \mathrm{K}$ : ketamine $10 \mathrm{mg} / \mathrm{kg}$ )

The rectal temperature of animal remain within normal values ranging from $39.6 \mathrm{C}$ and $39.5 \mathrm{C}$ in $\mathrm{D}+\mathrm{K}$ and $\mathrm{M}+\mathrm{K}$ groups respectively at the beginning of the injection then gradually decrease to reach $38.7 \mathrm{C}$ and $39.1 \mathrm{C}$ in $\mathrm{D}+\mathrm{K}$ and $\mathrm{M}+\mathrm{K}$ groups respectively figure (5). 


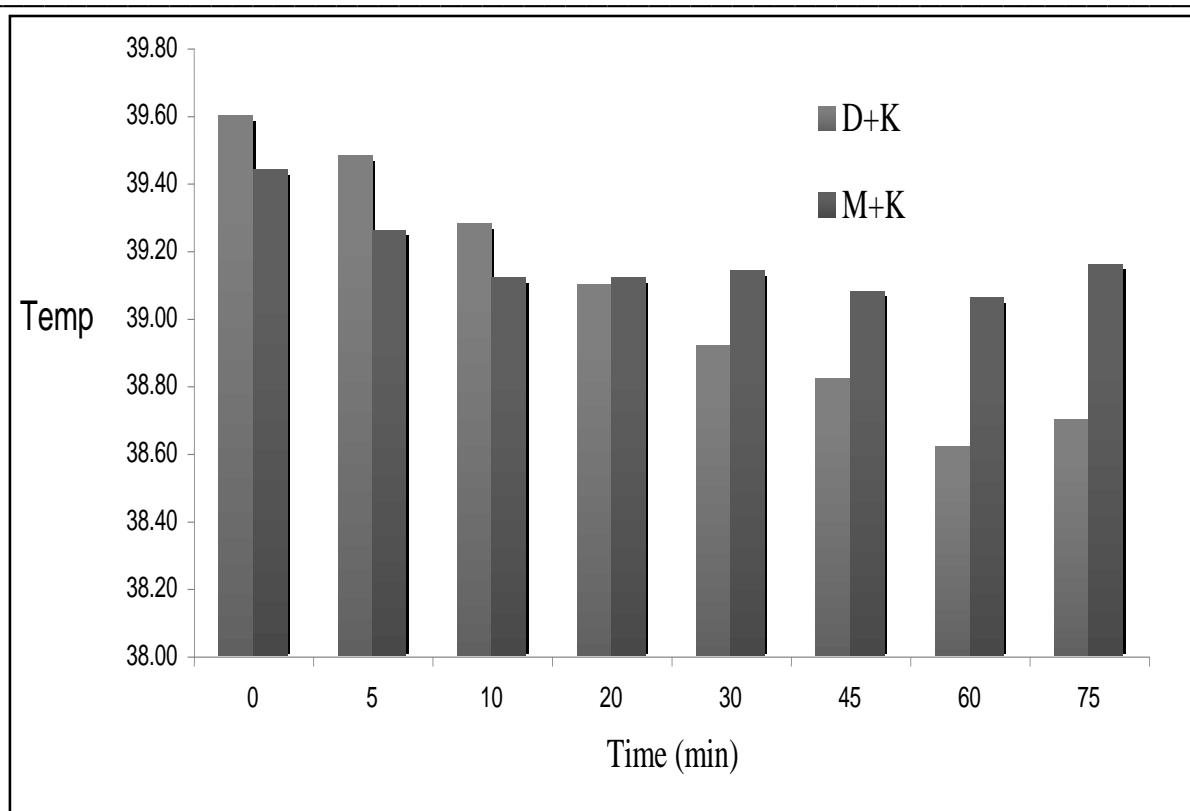

Figure (5) the effect of IM injection of $\mathrm{D}+\mathrm{K}, \mathrm{M}+\mathrm{K}$ on Temperature:

(D: Diazepam 1mg/kg, M: Midazolam 1mg/kg, K: ketamine 10mg/kg)

\section{Heart Rate}

The heart rate in $\mathrm{D}+\mathrm{K}$ group began to changed at $5 \mathrm{~min}$. after im injection of drug reach $113 \mathrm{Beat} / \mathrm{min}$. to elevated to 117-124 Beat/min. at $20 \mathrm{~min}$ and $30 \mathrm{~min}$. respectively then to stable nearly to 131Beat/min. at 45-60min., While in $\mathrm{M}+\mathrm{K}$ heart rate at $5 \mathrm{~min}$. after im injection reached to $132 \mathrm{Beat} / \mathrm{min}$. then gradually decrease to reach $120 \mathrm{Beat} / \mathrm{min}$. at $20 \mathrm{~min}$. then reach nearly from $120-122$ Beat $/ \mathrm{min}$. from $30 \mathrm{~min}$. to $75 \mathrm{~min}$ respectively figure (6).

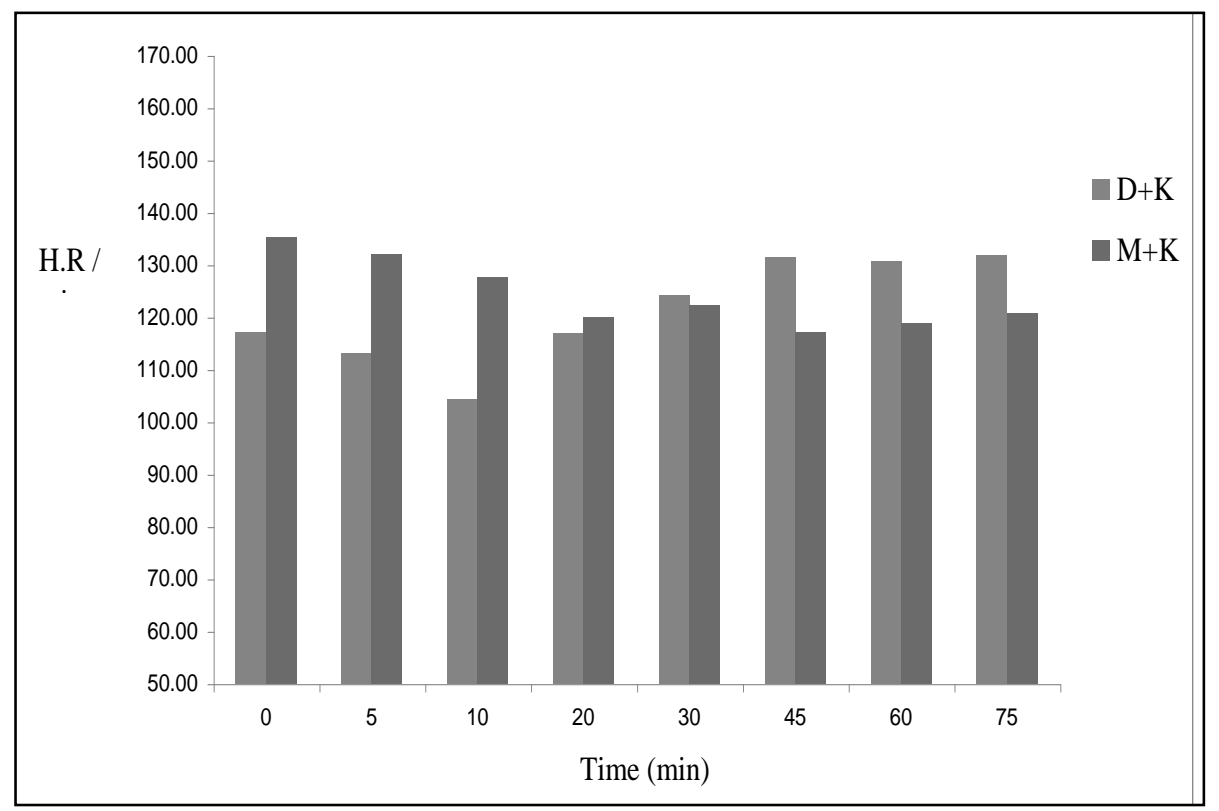

Figure (6) the effect of IM injection of $\mathrm{D}+\mathrm{K}, \mathrm{M}+\mathrm{K}$ on Heart Rate:

(D: Diazepam 1mg/kg, M: Midazolam 1mg/kg, K: ketamine 10mg/kg)

\section{Discussion}

Using of ketamine as a sole anaesthetic agent is usually associated with a lot of problems such as weak muscle relaxation, persistent pain reflex, violent recovery from anaesthesia and increased tonic-clonic muscle activity in most species of animals $(11,12)$. In order to overcome these shortcomes of ketamine it should be combined with other sedative agent such as xylazine, diazepam or 
midazolam.Diazepam and midazolam are classified as sedative, hypnotic and muscle relaxant drugs of benzodiazepines derivative, the animals that were injected diazepam show less comfortable and more excitement reaction after injection as compared with those injected midazolam, where midazolam is less irritable (13) than diazepam and that could be attributed to the presence of propylene glycol, irritant agent, in diazepam solution. Although midazolam is a water soluble compound has shorter half life time than that of diazepam thus has rapid onset of action and short recovery period $(1,14,15)$. Although ketamine is very good analgesic drug and the onset of analgesia occure rapidly (12), in MK group, the rapid action and metabolism of midazolam attributed to the midazolam is a imidazobenzodiazepine that differs structurally from other benzodiazepines by presence of an imidazole ring. In its closed form at physiological $\mathrm{pH}$, this ring imparts increased lipid solubility facilitating tissue penetration.The respiratory rate remain with normal range but short elevation was seen between 5-20min. in DK group followed by decreased reached the least at $45 \mathrm{~min}$. before its return to the normal at 60min. In MK group the respiratory rate remains like normal up to $20 \mathrm{~min}$. where decreased between 30-45-min. then return to normal, the depression in respiration is generally a consequence of depressing of brainstem and it could be postulated that the greater the depression of the brain (16, 17).Rectal temperature decreased in both groups, but there were no significant differences between them. The decrease in rectal temperature was probably occurred as a result of administration of benzodiazepines derivatives (diazepam and midazolam) because of central nervous system depression and a reduction of muscular activity. (18, 19).Both drugs midazolam and diazepam cause mild decrease in heart rate, but the MK group show more regular and slowly decrease (2, $3)$. Ketamine able to temporary counteract the bradycardia produced by midazolam and diazepam, where ketamine stimulates the central sympathetic outflow, which in turn, causes stimulation of the heart (20).It can be concluded that anaesthesia with Midazolam+Ketamine combination in sheep is suitable compared with Diazepam+Keatmine as it produce reliable surgical anaesthesia, good analgesia and muscle relaxation.

\section{References}

1- Hall, L.W. and Clarke, K.W. (1991). Veterinary anaesthesia 9th ed. Bailliere-Tindall. London.

2- Muir, W.W. and Mason, D.E. (1993). Effect of diazepam, acepromazine, detomidine and Xylazine on Thiamylal anaesthesia in horses. J. Am. Vet. Med. Assoc., 203(7): 10311038.

3- Ghurashi, M.A.H., Seri, H.I., Bakheit, A.H., Ashwag, E.A.M. and Abakar, J.A. (2009): Evaluation of Ketamine/diazepam Anaesthesia for Performing Surgery in Desert Goats under Field Condition. Australian Journal of Basic and Applied Sciences, 3(2): 455-459.

4- Thurmon, J.C., Jones, E., Lumb, W.V., Tranquilli, W.J. and Benson, G.J. (1996): Lumb \& Jones' Veterinary Anesthesia. 3th ed. Lippincott Williams \& Wilkins.
5- Mandrioli R., Mercolini L. and Raggi M.A. (2008): Benzodiazepine metabolism: an analytical perspective. Curr Drug Metab 9:827844

6- Short, C.E. (1987): Prindiples \& Practice of Veterinary Anesthesia. Lippincott Williams \& Wilkins.

7- Ersek, R., (2004) : Dissociative anesthesia for safety's sake: ketamine and diazepam-a 35-year personal experience. Plast Reconstr Surg 113:1955-1959

8- Stegmann, G.F., (1999): Observations on some cardiopulmonary effects of midazolam, xylazine and a midazolam/ketamine combination in the goat. JSAVA 70:122-126

9- Ismail, Z.B., Jawasreh, K. and Al-Majali, A. (2009): Effects of xylazineketamine-diazepam anesthesia on blood cell counts and plasma biochemical values in sheep and 
goats. Comp Clin Pathol 10: 580585.

10- Snedecor, G W and Cochran, W G. (1980) Statistical methods. $7^{\text {th }}$ edition, Iowa State University Press, Ames, Iowa.

11- Riebold, T.W. (1996). Ruminants. In: Lumb \& Jones, Veterinary Anaesthesia (3rd edn). Thurmon JC, Tranquilli WJ, Benson GJ (eds). Williams \& Wilkins, Baltimore, USA, pp. 610-626.

12- Hall, L.W., K.W. Clarke and Trim, C.M. (2001). Veterinary anaesthesia. 10th edition. W.B. Saunders, London.

13- Jaimovich, D.G., Osbore, J.S. and Shabino, C.L. (1992): comparison of intravenous and endotracheal administration of midazolam and the effects on pulmonary function and histological. Kmb. Ann. Energ. Med. 21 480-485.

14- Kyles, A.E., Waterman, A.E. and Livingston, A. (1995): Antinociceptive activity of midazolam in sheep. J. vet Pharmacol. Therap. 18, 54-60.

15- Celly, C.S., McDonell, W.N., Black, W.D. and Young, S.S. (1997): Cardiopulmonary effects of clonidine, diazepam and the peripheral $\alpha 2$ adrenoceptor agonist
ST-91 in conscious sheep. J. vet. Pharmacol. Therap. 20, 472 \pm 478 .

16- Kul, M., Koc,Y., Alkand , F. and Z. Ogurtan, (2000): The effects of Xylazine-Ketamine and diazepamKetamine on arterial blood pressure and blood gases in dogs. J. Vet. Res., 4: 122-132.

17- Upton, R.N., Martinez, A. M. and Grant, C., (2009): Comparison of the sedative properties of CNS 7056, midazolam, and propofol in sheep. British Journal of Anaesthesia 103 (6): $848-57$

18- Nuh kilic (2008): Cardiopulmonary, Biochemical and Haematological changes after DetomidineMidazolam-Kitamine anaesthesia in Calves. Bull Vet Inst Pulawy 52, 453-456, 2008

19- Grint, N.J. and Murison, P.J. (2007): perioperative body temperature in isoflurane anaesthetized rabbits following ketamine-midazolam or ketamine-medetomidine. Vet. Anaesth. \& Analg., 34 181-189.

20- Harvey, R.H., Champe, P.C., Mycek, M.J. (2000): Lippincott's Illustrated Reviews: Pharmacology. $2^{\text {nd }}$ edition. Lippincott Williams \& Wilkins.

\section{دراسة مقارنة بين استخدام خلطة الميدازولام+الكيتامين و خلطة الايازيبام+الكيتامين كبرنامج تخدين الخديري في الاغنام}

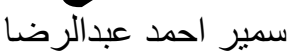

كلية الطب البيطري/ جامعة القادسية

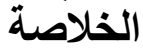

صمدت هذه التجربة لمقارنة فعالية استعمال اثثين من الخلطات التخديرية (الديازيبام+ الكيتامين)

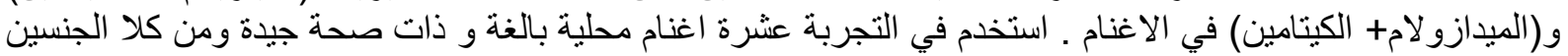

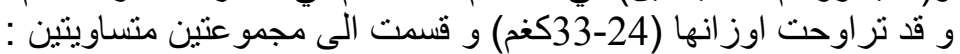

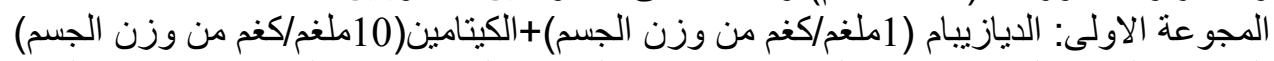

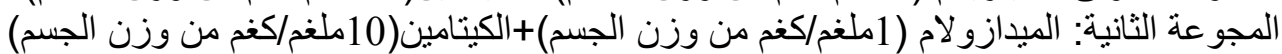

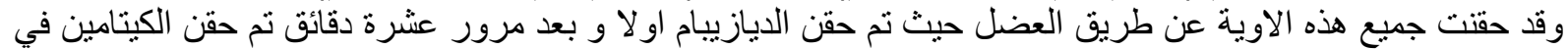

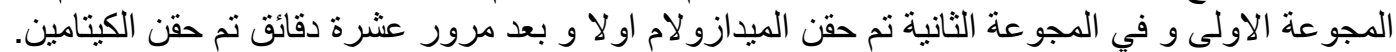

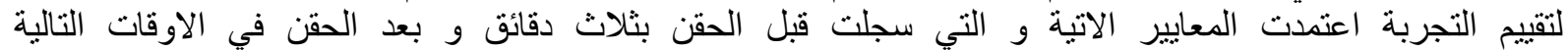

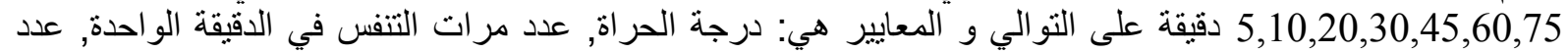

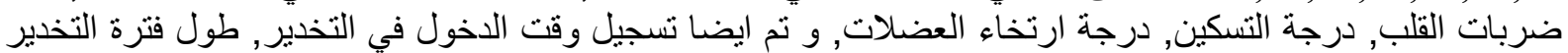

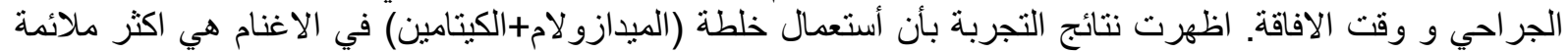

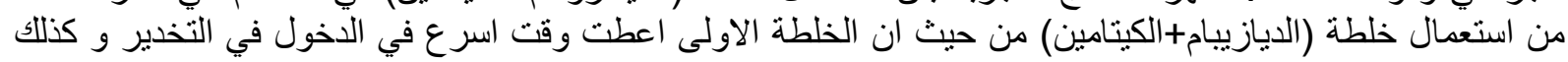

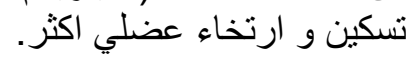

